\title{
REVIEW Imprinting M echanisms
}

\section{Miguel Constância, ${ }^{1}$ Benjamin Pickard, Gavin Kelsey, and Wolf Reik ${ }^{1}$}

\author{
Programme in Developmental Genetics, The Babraham Institute, Cambridge CB2 4AT, UK
}

A number of recent studies have provided new insights into mechanisms that regulate genomic imprinting in the mammalian genome. Regions of allele-specific differential methylation (DMRs) are present in all imprinted genes examined. Differential methylation is erased in germ cells at an early stage of their development, and germ-line-specific methylation imprints in DMRs are reestablished around the time of birth. A fter fertilization, differential methylation is retained in core DM Rs despite genome-wide demethylation and de novo methylation during preimplantation and early postimplantation stages. Direct repeats near CG-rich DM Rs may be involved in the establishment and maintenance of allele-specific methylation patterns. Imprinted genes tend to be clustered; one important component of clustering is enhancer competition, whereby promoters of linked imprinted genes compete for access to enhancers. Regional organization and spreading of the epigenotype during development is also important and depends on DMRs and imprinting centers. The mechanism of cis spreading of DNA methylation is not known, but precedent is provided by the Xist RNA, which results in X chromosome inactivation in cis. Reading of the somatic imprints could be carried out by transcription factors that are sensitive to methylation, or by methyl-cytosine-binding proteins that are involved in transcriptional repression through chromatin remodeling.

Genomic imprinting is an unusual yet important mechanism of gene regulation by which only one of the parental copies of a gene is expressed (Fig. 1). Although it has been known for some time that DNA methylation is involved in imprinting, the details of how imprints are introduced in the parental germ cells, maintained in embryos, and used to express or repress genes have been elusive. However, recently a number of advances have been made: (1) the definition of cis-acting sequences that are important in the control of imprinting; (2) the developmental analysis of how and when imprints are established in germ cells (and when they areerased); and (3) how imprints are maintained, particularly during preimplantation development at which time major changes in methylation occur throughout the genome (Fig. 1). It has also become apparent that imprinted genes tend to be clustered and that aspects of imprinting control are regional and shared between genes in the cluster. Although the reading of the imprint (i.e., the translation of somatic imprint into gene expression pattern) is usually considered to be a more general aspect of epigenetic gene regulation (and therefore not unique to imprinted genes), we describe briefly the known mechanisms that could be involved. Here we consider these recent advances that make the study of

${ }^{1}$ Corresponding authors.

E-MAIL wolf.reik@bbsrc.ac.uk; miguel.constancia@bbsrc.ac.uk; FAX 44 (0) 1223836481. imprinted genes particularly instructive as a major example of epigenetic gene regulation in mammals, with important implications for disease when deregulated. The sectionsin the first half of this review describe the properties of imprinted genes at key stages of germ cell and embryonic development (Fig. 1). The nature of the molecular elements that combine to initiate and maintain the imprint and also translate it into monoallelic expression form the focus of sections in the second half of the review.

The Germ Line

Erasure

The germ line has the crucial role of erasing existing imprints that are inherited from the previous generation, and establishing the imprints, according to the sex of the germ line, for the next (Fig. 1). Two models have been envisaged for how this might occur (Rossant 1993). In the first, the epigen otype (imprint) of the same sex chromosome is maintained, whereas the one of the opposite sex is reversed. This could be a single step mechanism. In the second, the existing epigenetic modifications are first erased from both parental chromosomes in both germ lines, and imprints are then established in a sexspecific fashion at a later stage. During the past few years, considerable insights have been gained from methylation, expression, and functional studies of 


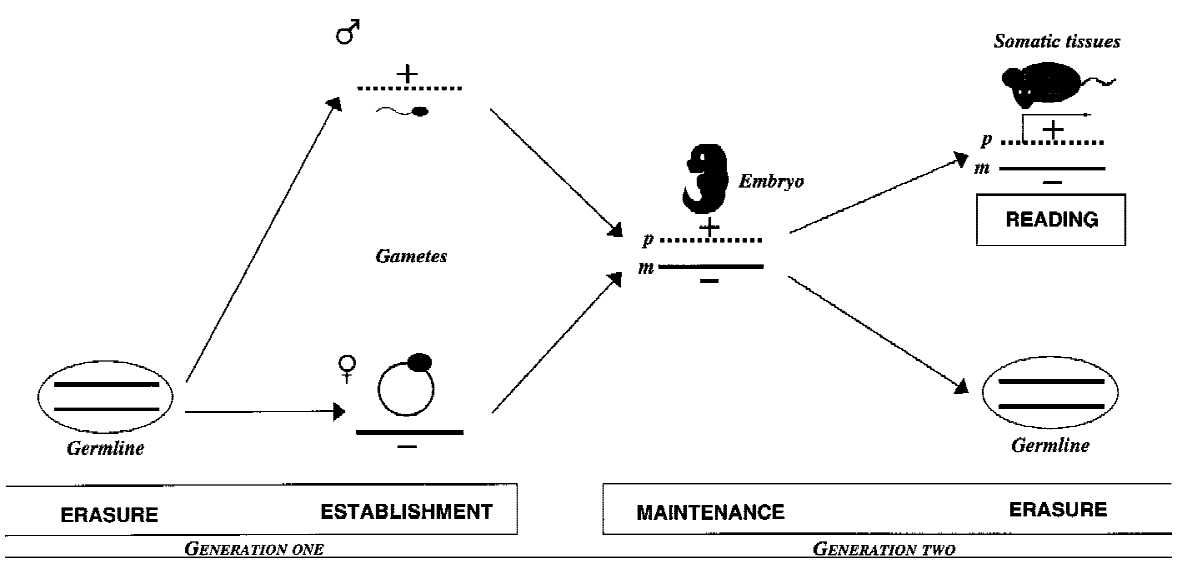

Figure 1 Key stages of genomic imprinting during development. (Erasure) The "imprint" (inherited from the previous generation, generation one) is erased on both parental chromosomes during germ cell development (note that this figure shows complete erasure of all imprints in the germ line, which is one of two models discussed in the text). (Establishment) A new imprint is established (+or $-)$, according to the sex of the germ line, for the next generation (generation two). (Maintenance) The imprint is stably propagated during mitosis; although not part of the developmental cycle of imprinting, the maternal $(\mathrm{m})$ and paternal (p) imprints are translated into monoallelic expression (indicated by arrow) during development (Reading). Successive cycles of erasure, establishment, and maintenance are a key characteristic of the imprinting process.

germ cells. These studies begin to tip the balance toward the second model.

Germ cells develop from a founder population of $\sim 45$ cells derived from the epiblast and are determined by day 7.5 of mouse embryonic development (E7.5). Primordial germ cells (PGCs) migrate through extraembryonic regions and the hindgut to their final destination, the gonad primordia in the genital ridge, by E10.5-E11.5 (for review, see Buehr 1997). At E13.5 female germ cells enter the meiotic prophase, whereas male germ cells undergo mitotic arrest. Spermatogonia resume mitosis after birth, which is followed by meiotic differentiation. Oocytes undergo growth after birth, before being ovulated and fertilized.

Although it is clear that DNA methylation has a crucial role to play in imprinting, it is not established whether methylation is the primary imprinting signal that needs to be removed and reestablished in the germ line. However, it appears that methylation changes in imprinted genes in the germ line are at least temporally associated with altered functional properties of the germ cells (see below). Therefore, even if methylation is not the primary imprinting signal, it is likely to be related to such a signal.

Global demethylation and methylation events occur in germ cells. By E12.5-E13.5 all nonimprinted sequences tested so far are demethylated in both sexes (Sanford et al. 1987; Kafri et al. 1992). This is followed by remethylation from E15.5 in many gene sequences (except CpG islands) with only certain sequences retaining methylation differences between oocyte and sperm genomes (Sanford et al. 1987; Kafri et al. 1992). However, it is possible that the germ line occasionally fails to reprogram epigenetic information. This would lead to epigenetic inheritance through the germ line, which has been observed both for transgene methylation patterns (Sapienza et al. 1989; Allen et al. 1990) and endogenous sequences (Römer et al. 1997).

The global demethylation occurring at early stages of germ cell development also includes imprinted genes (Brandeis et al. 1993). Hence, Igf2r, p57 Kip2, Peg1, Peg3, Snrpn, U2afrs1, and N nat are all demethylated by E12.5 (Fig. 2; Brandeis et al. 1993; Tada et al. 1998). H19 and Igf2 are not completely demethylated and slightly higher levels of methylation are present in male compared to female PGCs (Tada et al. 1998; H. Sasaki, pers. comm.). This is based on direct examination of PGCs or inferred from the use of embryonic germ (EG) cell lines. Little is known about stages before E12.5 except for one study of E8.5 EG cells that found that the maternal methylation of I $g f 2 r$ region 2 was still present in some cell lines, suggesting that demethylation takes place between E8.5 and E12.5 (Labosky et al. 1994). This timing is partly supported by functional studies. Although chimeras made with E8.5 EG cells develop normally (Labosky et al. 1994), those made with E12.5 EG cells (from both sexes) show enhanced fetal growth, lethality, and skeletal malformations (some of these phenotypes are characteristic of androgenetic chimeras) (Labosky et al. 1994; Tada et al. 1998). In these chimeras, hypomethylation was observed in the normally maternally methylated genes, and Igf $2 r$ was repressed (which together with expected biallelic expression of paternal genes would contribute to the androgenetic-like phenotype). H19 and Igf2 seemed to be $50 \%$ methylated in chimeras, suggesting that these imprints were retained at E12.5 when 


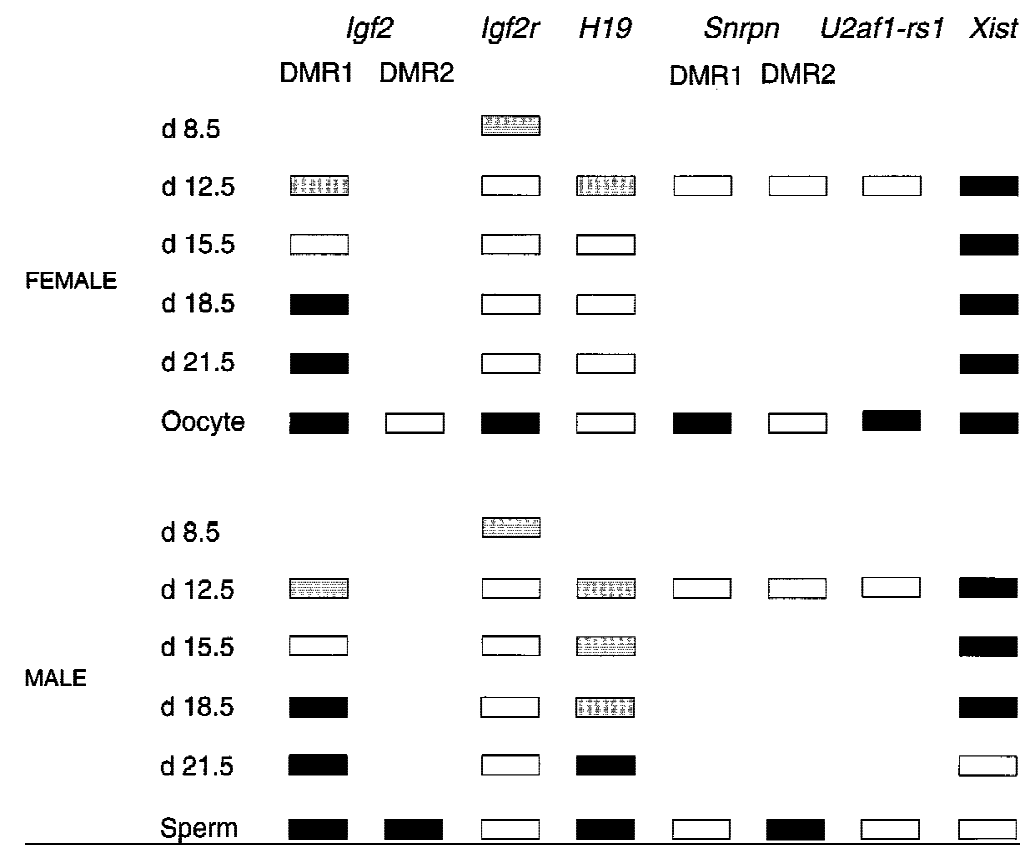

Figure 2 Methylation patterns in imprinted genes in the germ line. The stages of germ cell development analyzed for each imprinted gene are indicated. (Solid box) Complete methylation; (shaded box) partial methylation; (open box) no methylation. (See text for details and references.) (DMR) Differentially methylated region.

the EG cells were derived (Tada et al. 1998). Whether the paternal copy of H19 becomes demethylated (erased imprint) in male germ cells at any stage is not clear (see below). However, Igf2, H19, Igf2r, and Snrpn are all biallelically expressed in both germ lines beginning from E11.5 (Szabo and Mann 1995; Villar et al. 1995), suggesting that imprints are indeed largely erased (or not recognized) at these stages.

Fusion experiments between EG cells and thymic lymphocytes show that EG cells have a dominant demethylating activity that acts on imprinted as well as nonimprinted genes and repeat sequences (Tada et al. 1997). The only sequences so far detected that might escape this global demethylation in early germ cells seem to be the $5^{\prime}$ region of $X$ ist, which remains methylated in both sexes (Fig. 2; Ariel et al. 1995; Razin and Shemer 1995) and the paternal copy of H19 in male germ cells as mentioned above (H. Sasaki, pers. comm.).

\section{Establishment}

The timing of methylation establishment in imprinted genes is quite clear for the female, but less clear for the male germ line (Fig. 2). In the female, oocytes in dictyate stage arrest (from E13.5) are apparently not methylated until after birth, when methylation occurs during oocyte growth. This has been established for repeat sequences (Howlett and Reik 1991), Igf2r (Brandeis et al. 1993; Stöger et al. 1993), imprinted transgenes (Chaillet et al. 1991; Ueda et al. 1992), and inferred for Peg1, Peg3, and Snrpn from functional studies (see below). These methylation events are coincident with the presence of high levels of DNA methyltransferase (Dnmt1) in the nucleus of the growing oocyte (Mertineit et al. 1998). Whether other imprinted genes that remain unmethylated in the oocyte (e.g., H19) are specifically protected from de novo methylation at these stages is not known. That such protection may be necessary is indicated by the fact that the p5 $7^{\mathrm{Kip} 2}$ gene, which is normally paternally methylated, and is demethylated in EG cells, became de novo methylated in EG cell chimeras (Tada et al. 1998). As pointed out above, the establishment of imprinted gene methylation in the male germ line is less clearly defined (Fig. 2). However, $\mathrm{H} 19$ and Igf 2 methylation is apparently established around the time of birth (Brandeis et al. 1993; H. Sasaki, pers. comm.). This is again coincident with high levels of Dnmtl protein in nuclei of spermatogonia (Mertineit et al. 1998). Whether the grandpaternal copy of H19 becomes completely demethylated before this de novo methylation occurs is not clear (H. Sasaki, pers. comm.). It has been proposed that $\mathrm{H} 19$ is targeted specifically for de novo methylation in male germ cells, rather than being protected from it in female ones (Surani 1998).

Two sets of functional studies have examined germ cells by nuclear transplantation at presumed stages of erasure and before establishment. Gynogenetic embryos have been prepared with the second maternal genome originating from ungrown oocytes (Kono et al. 1996; Obata et al. 1998). These embryos show improved development when compared to gynogenetic ones, and express the (presumably unmethylated) Peg1, Peg3, and Snrpn genes. In contrast, Igf $2 \mathrm{r}$ and $\mathrm{p} 57^{\mathrm{Kip2}}$ were repressed in the genome originating from the immature oocyte, showing again that they need to be methylated for activity. The nucleus from male germ cells from E15.5 to E16.5 was also transplanted, and chimeras were obtained in which the transplanted nucleus participated in embryonic and extraembryonic development to E10.5 (Kato and Tsunoda 1995). Inas- 
much as androgenetic cells are not expected to contribute to embryonic development in chimeras (they contribute to extraembryonic tissues), this may indicate that these germ cells are still at a stage before acquiring the paternal imprints.

Genetic observations of "imprinting mutations" in the Prader-Willi/Angelman syndromes (PWS/AS) have indicated previously that such mutations may interfere with the required switch in epigenotype in the germ lines (Horsthemke et al. 1997). It has been proposed that such mutations prevent the chromosome of the opposite parental sex switching epigenotype, but do not affect the epigenotype of the same sex chromosome (Horsthemke et al. 1997). This would appear to lend support to the "same sex, no reprogramming" hypothesis. However, as argued previously, these observations are not conclusive and do not currently allow the distinction between the models (Kelsey and Reik 1997; Reik and Walter 1998).

The Embryo

O ntogeny of Allelic Methylation

The ontogeny of DNA methylation at imprinted loci after fertilization, as in the germ line, has to be seen in the context of the genome as a whole and the global changes in methylation that occur during early embryonic development. Much of the methylation arriving with the gametes, including the gross difference between the maternal and paternal genomes, is erased rapidly during preimplantation development. The higher methylation levels that characterize adult somatic tissues begin to be laid down after implantation, with the onset of general de novo methylation (Monk et al. 1987; Sanford et al. 1987; Howlett and Reik 1991; Kafri et al. 1992; Yoder et al. 1997a). The essential role of methylation in development is indicated by the midgestational failure of mouse embryos that lack the product of the DNA methyltransferase gene Dnmt1 (Li et al. 1992; Lei et al. 1996); abnormal ities include the deregulation of imprinted gene expression ( $\mathrm{Li}$ et al. 1993).

The enzymology of the embryonic demethylation and remethylation events is beginning to be understood. The principal DNA methyltransferase is Dnmt1, in addition to its activity as a maintenance methylase, through its action on hemimethylated DNA at replication, Dnmt1 has also been suggested to bethe predominant de novo methylation activity in mouse embryos (Yoder et al. 1997b). Although present in abundance as a maternal gene product in early embryos, the protein is cytoplasmic during the first cleavage stages, except for a brief appearance in the nucleus at the eight-cell stage, and becomes local ized in nuclei only at implantation (Carlson et al . 1992; Trasler et al. 1996; Mertineit et al. 1998). Therefore, generalized demethylation could come about by a passive dilution of methyl groups at each cell division (Howlett and Reik 1991). In addition, demethylation in early embryos may occur by an active process (Kafri et al. 1993). A demethylating activity has been characterized partially in vitro, in extracts of myoblast and embryonic carcinoma (EC) cells, and is mediated by an RNA component, whose activity, sequence specificity, or cell-type specificity may be modulated by protein factors (Weiss et al. 1996). De novo methylase activity, as measured by methylation of newly integrated retroviral DNA, is readily detected in mouse embryonic stem (ES) cells (which derive from the inner cell mass of the blastocyst) and in undifferentiated EC cells, but is down-regulated in differentiated EC cells and postimplantation embryos (Jähner and Jaenisch 1984; Lei et al. 1996). Undifferentiated ES cells in which the Dnmtl gene has been homozygously deleted retain a low level of genomic methylation and the ability to methylate retroviral DNA (Lei et al. 1996), indicating the existence of methyltransferase activities in addition to Dnmtl.

If the methylation that distinguishes parental alleles in the gametes does have a role in determining allele-specific expression, or at least coincides with functionally important sequences, it might be anticipated to resist the early demethylation/ remethylation cycle of the remainder of the genome. Evidence for such methylation differences has been found at several imprinted loci. The best characterized gametic imprint is at the mouse $\mathrm{H} 19$ gene, located 2-4 kb upstream of the start site, where the paternal, repressed al lele is heavily methylated, and the maternal allele hypomethylated in mid-gestation embryos (Bartolomei et al. 1993; Ferguson-Smith et al. 1993; Tremblay et al. 1995). Differential methylation extends over 59 CpG dinucleotides, as shown by bisulfite genomic sequencing (Olek and Walter 1997; Tremblay et al. 1997). The difference between sperm and oocyte is al most absolute, but soon after fertilization (by the eightcell stage) some modification of the pattern inherited from the gametes has occurred, with limited de novo methylation on the maternal allele and demethylation of the paternal allele toward the upstream extreme of the region (Fig. 3). However, a strong methylation difference is maintained across much of the region throughout preimplantation 

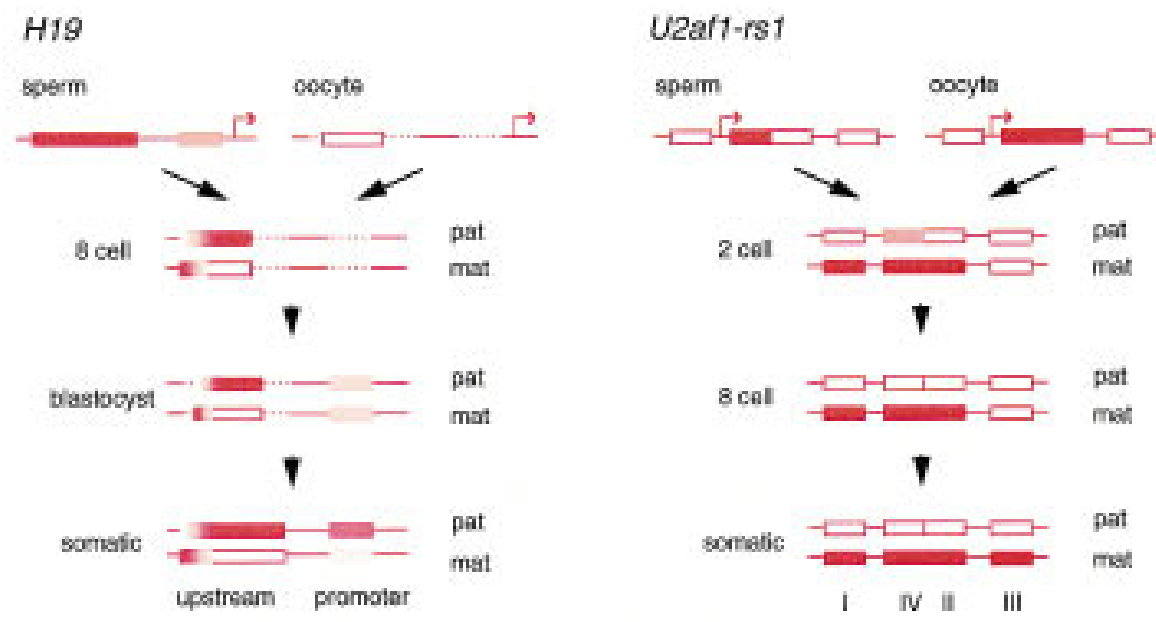

Figure 3 The ontogeny of allelic methylation at the H19 and U2af1-rs1 genes. (Solid bars) Complete methylation ( $>90 \%$ ); (open bars) absence of methylation $(<10 \%)$; (shaded bars) intermediate levels. Dashed lines represent regions not analyzed at the indicated stages. The locations of the transcription start sites are indicated by the arrows in the top line (which are not intended to represent actual expression status). The scheme for $\mathrm{H} 19$ represents a composite of two bisulfite genomic sequencing studies (Olek and Walter 1997; Tremblay et al. 1997). The upstream differentially methylated region comprises $59 \mathrm{CpG}$ dinucleotides, of which 27 were assayed in oocytes and eight-cell embryos (Olek and Walter 1997) and 14 in blastocysts (Tremblay et al. 1997); the promoter proximal region comprises $9 \mathrm{CpG}$ dinucleotides. The methylation of maternal and paternal alleles in two-cell embryos did not differ from the gametes in the regions analyzed (Olek and Walter 1997). The scheme for U2af1-rsl derives from a PCR analysis of the methylation of restriction sites by Shibata et al. (1997). Each region contains multiple sites for Hpall and Hhal. Therefore, precise levels of methylation at individual sites cannot be inferred. Methylation at the one-cell stage did not differ from the gametes.

and later development. In contrast, closer to the promoter, differential methylation is less pronounced. Both parental alleles are relatively hypomethylated in the blastocyst, although methylation was high in sperm. The higher level of methylation of the paternal allele is attained in the embryo postimplantation (Tremblay et al. 1997).

Rapid postzygotic changes in methylation have also been described in some detail at the mouse U2af1-rs1 gene, although without the resolution of the bisulfite approach (Shibata et al. 1997). A gametic difference exists in the tandem repeat containing 5' UTR (region II, Fig. 3). Exclusive maternal allele methylation is retained throughout preimplantation development and into somatic tissues. A flanking part of the 5' UTR (region IV) is methylated in both gametes and in one-cell embryos, but methylation is lost from the paternal allele from the twocell stage. In contrast, the promoter (region I) is unmethylated biallelically to the one-cell stage, and methylation specifically on the maternal allele is detected first at the two-cell stage. Further methyl- ation of the maternal allele occurs after implantation, exemplified by region III within the gene.

These two examples reveal a very dynamic pattern of methylation at imprinted genes during preimplantation development. More limited PCR analysis has shown the existence of gametic imprints at the Igf2r, Snrpn, and Grf1/ $\mathrm{Cdc} 25 \mathrm{Mm}$ genes (Brandeis et al. 1993; Stöger et al. 1993; Shemer et al. 1996, 1997; Shibata et al. 1998), with some indication of similar remodeling. There are several implications of such dynamic behavior. First, a "core" of differential methylation exists, which is retained throughout development (described henceforth as a core differentially methylated region, core DM R). Remodeling of methylation occurs at sites flanking the core DMR from very early stages, which ultimately stabilize to produce the allelic methylation of somatic tissues. Second, the two alleles may be undergoing simultaneously opposing modification processes. In this, differential methylation runs counter to two trends; methylation on one allele is protected from the general demethylation occurring over the rest of the genome, and hypomethylation of the other must resist the subsequent global remethylation. It is possible that an unusually high density of ${ }^{\mathrm{Me}} \mathrm{CpG}$ at a $\mathrm{CpG}$ island-like sequence (nonimprinted $\mathrm{CpG}$ islands in contrast remain hypomethylated) is sufficient to resist demethylation (Howell et al. 1998). In addition, the protection of $\mathrm{CpG}$ islands from de novo methylation afforded by the transcription factor Spl offers some precedent for the resistance of the unmethylated allele to modification (Brandeis et al. 1994; Macleod et al. 1994). If methylation is lost from a core DMR, as occurs in Dnmt1 ${ }^{-1-}$ ES cells, returning methyltransferase activity cannot restore it, without passage through the germ line (Tucker et al. 1996). This might indicate that once methylation has been erased from the normally methylated allele, remethylation is prevented in somatic tissues by the same 
factors that protect against methylation of the normally unmethylated allele.

Somatic M aintenance of Allelic M ethylation

As implied above, gametic imprints represent only a part of the differential methylation at imprinted loci in somatic tissues. At the H19 gene, for example, methylation of the paternal, repressed allele extends to the promoter and encompasses the body of the gene during postimplantation development (Bartolomei et al. 1993; Ferguson-Smith et al. 1993; Sasaki et al. 1995). Likewise, at the Igf2r gene, the repressed promoter of the paternal allele becomes methylated only late in gestation (Stöger et al. 1993). Such differential methylation may thus be regarded as a secondary effect, possibly in response to transcriptional inactivity, as it arises after monoallelic expression has become established.

Differential methylation need not involve the whole gene or the entirety of a region containing a cluster of imprinted genes. For the small intronless U2af1-rs1 gene, methylation does extend over the entire length of the repressed maternal allele, with the paternal copy being hypomethylated (Shibata et al. 1996; Feil et al. 1997). Generally, however, parental allele-specific methylation appears to be restricted to discrete elements. At Igf2r, a gene spanning $\sim 90 \mathrm{~kb}, \mathrm{DMRs}$ occur at the promoter and the gametic imprint in intron 2, elements separated by $\sim 30 \mathrm{~kb}$ (Stöger et al. 1993). At the Igf2/H 19 cluster, differential methylation is confined to the $\mathrm{H} 19$ gene (Bartolomei et al. 1993; Ferguson-Smith et al. 1993) and three elements in Igf2: DMR0 and DMR1 in upstream introns and DMR2 around the final intron (Feil et al. 1994; Moore et al. 1997). The CpG island at Igf2 promoter P2 is unmethylated biallelically (Sasaki et al. 1992) and the 70-kb region between $\mathrm{H} 19$ and Igf2 has equal levels of methylation on both chromosomes (Koide et al. 1994). However, differential methylation of these elements does depend on the integrity of the presumed imprinting signals associated with core DMRs. Deletion of the $\mathrm{H} 19$ gene, including the upstream region, leads to altered methylation at the three Igf2 DMRs on the same parental allele (Forné et al. 1997; Moore et al. 1997). In the Prader-Willi syndrome (PWS), imprinting mutations including deletion of the DMR at the "imprinting center" at the SNRPN CPG island result in altered methylation in cis of loci over a region of at least $1 \mathrm{Mb}$ (Horsthemke 1997). One model foresees that such "secondary" DMRs may represent staging posts in the spreading of the imprinted epigenotype across a cluster of imprinted genes outward from an imprinting center represented by the core DMR (Reik and Walter 1998).

In general, methylation effects have shown little tissue-specific variation. Differential methylation of the $\mathrm{H} 19$ gene occurs in liver and brain, despite expression in the former and not in the latter, and is not altered after the postnatal repression of the gene (Bartolomei et al. 1993). Other imprinted genes that show pronounced tissue-specific variation in expression levels general ly have constitutive differential methylation. At the Igf2 gene, in contrast, tissue-specific DMRs have been described. DMRO is methylated on the repressed maternal allele specifically in placenta (Moore et al. 1997); methylation at DMR2 is restricted to the paternal allele in liver and other endoderm-derived tissues (Feil et al. 1994). It is possible that such methylation reflects tissue-specific transcription effects; DMRO, for example, is located close to noncoding upstream exons restricted to placental transcripts. It remains to be seen whether genes that are widely expressed but subject to highly tissue-specific imprinting, such as Gnas and Ube3a (Williamson et al. 1996; Albrecht et al. 1997), will show equally tissuespecific differential methylation, or whether they also contain core DMRs that could serve as a memory of parental origin in all tissues.

Allelic methylation differences are generally regarded to be stable in somatic tissues once established in the embryonic phase. Cultured fibroblasts are reluctant to express the maternal Igf2 allele, unless challenged with agents such as 5azadeoxycytidine (an inhibitor of methyltran sferase) or sustained growth arrest (Eversole-Cire et al. 1993; Ungaro et al. 1997). Changes in epigenotype leading to relaxation of imprinting are also encountered in pathological situations, where they might be seen to offer a selective advantage on cellular phenotype. Biallelic methylation of the $\mathrm{H} 19$ promoter occurs frequently in Wilms' tumor of the kidney. The silencing of the normally active maternal H19 promoter may lead to derepression of the maternal IGF2 allele, through competition with the shared enhancers (M oulton et al. 1994; Steenman et al. 1994), resulting in a growth advantage from enhanced IGF2 expression. "Relaxation" of IGF2 and $\mathrm{H} 19$ imprinting is a frequent occurrence in many tumor types.

\section{Cis-A cting Signals}

Tandem Repeats

What is the evidence that DMRs define cis-acting 
sequences involved in the establishment or maintenance of imprinting? H19 transgenes having deletions of the core DMR fail to show correct imprinting, but other interventions within $\mathrm{H} 19$ transgenes al so impair imprinting (Pfeifer et al. 1996; Elson and Bartolomei 1997). When assayed in Drosophila (whose genome is unmethylated) this region functions as a cis-acting silencer (Lyko et al. 1997). Deletion of the core DMR (region 2) of the lgf $2 r$ gene in the context of transgenic yeast artificial chromosomes (YACs) also eliminates imprinting of the transgene (Wutz et al. 1997). The PWS “imprinting mutations" are small deletions including the DMR at the CpG island of the SNRPN locus, which may lead to incorrect resetting of the imprint in the paternal germ line (Horsthemke 1997). A similar deletion at the mouse Snrpn gene has now also been shown to block the switch from maternal to paternal epigenotype (Yang et al. 1998). Does this knowledge help to identify key cis-acting sequences? One provocative finding has been the association of short tandem repeats with DMRs.

Neumann et al. (1995) first proposed that direct tandem repeats, embedded in CG-rich sequences and associated with regions of differential methylation, may constitute a feature common and possibly unique to imprinted genes. This hypothesis was based on the concept that the imprinting mechanism may have evolved from the host defense function of DNA methylation (Barlow 1993). For example, an insertion of a retrovirus-like intracisternal A-particle (IAP) upstream of the mouse agouti locus can induce imprinting. The resulting ectopic expression of agouti is silenced specifically with paternal transmission, correlating with hypermethylation of the IAP long terminal repeat sequence (Michaud et al. 1994). Therefore, sequences with properties of "foreign DNA" may have been recognized by components of the methylation system to attract allelespecific modification and given rise to imprinting (Barlow 1993).

Many, if not all, imprinted genes contain tandem direct repeats. However, comparison of such direct repeats reveal $s$ few obvious common features. No sequence homology can be found between repeats in different genes (the consensus sequences tend, however, to be G-rich); the repeat units can be of different lengths, and the number of times they are repeated is variable; their location with respect to the gene also differs (upstream, 5' UTR, intronic; some being transcribed, others not) as does their relationship with CpG islands and allele-specific methylation patterns (they are found within, or at variable distances from CpG islands or DMRs). A comparison between mouse and human regarding a possible role for the repeats is not conclusive. The IGF2 gene in humans lacks a repeat in the homologous region to the mouse and yet is imprinted (Moore et al. 1997). A block of repeats may, however, exist further upstream of IGF2, as reported for the $\mathrm{H} 19$ gene (Jinno et al. 1996). On the other hand, the tandem repeat region and differential methylation in the U2af1-rs1 5' UTR is specific to this gene; related U2af1-rs loci in the mouse and human genomes lack this sequence feature and are biallelically expressed (Shibata et al. 1997). Finally, the IGF2R gene is polymorphically imprinted in humans (Xu et al. 1993) but contains numerous large direct repeats and is differentially methylated (Smrzka et al. 1995). What experimental evidence supports a role for these repeats in the establ ishment or maintenance of imprinting, given this diversity of properties?

Imprinting of the RSVIgmyc mouse transgene, which expresses the c-myc oncogene derived from a translocation, seems to require a cis-acting signal that is principally derived from the tandemly repeated sequences that make up the $3^{\prime}$ portion of the murine immunoglobulin a (IgA) heavy-chain switch region (Chaillet et al. 1995). Sequence context also seems to be important for imprinting, as the sequence elements of RSVIgmyc are not imprinted in their normal endogenous location. A recent analysis of additional mutations of the RSVIgmyc transgene, however, indicates that the IgA repeat sequences are not absolutely required for transgene imprinting (Howell et al. 1998). Similar results have also been observed with $\mathrm{H} 19$ transgenes; deletion of the G-rich repeat upstream of $\mathrm{H} 19$ eliminates transgene imprinting ( $M$. Bartolomei, pers. comm.). However, a larger transgene carrying this deletion did, in fact, show imprinted expression (M. Bartolomei, pers. comm.). These observations suggest that the repeats, although potentially important for attracting allele-specific methylation and expression, are not sufficient and must interact with other sequence features or context. Furthermore, although deletion of the repeat-containing region from an I $2 \mathrm{r}$ YAC abolishes imprinting, shorter transgenes that contain the repeats fail to attract parental-specific methylation (Wutz et al. 1997).

These results suggest the possibility of a redundant role for different sequence elements in governing imprinting. Different sequence el ements may be able to compensate for the loss of others. A model can beenvisaged in which imprinted genes are characterized by a set of combinatorial cis elements 
spread out in regions of the gene. Ultimately, it would be their organization or context (rather than sequence) that confers imprinting potential. These elements may constitute a network of responsive elements, under the hierarchical control of imprinting centers.

Although the role of direct repeats needs to be better defined by more precise genetic experiments, their involvement can be envisaged in a number of ways. Because organizational conservation rather than sequence homology is observed, secondary DNA structure may play an important role. Repeats may form alternative secondary structures that attract de novo methylation either in the gametes or soon after fertilization. Alternatively, the repeats could nucleate specific chromatin structures and the observed methylation patterns would be a consequence of this. Either way, germ-line-specific factors that protect one allel e from these modifications need to be involved (Fig. 4); for instance, methylation at Alu repeats is blocked in sperm by an Alubinding protein (SABP) (Chesnokov and Schmid 1995).

We propose a model in which the allele-specific methylation patterns at imprinted loci are established in regions where opposing de novo methylation signals (emanating from repetitive elements) and demethylation signals (induced by CpGrich environment) interact (Fig. 4). Trans-acting factors dictate the allele-specific patterns by either blocking the de novo methylation or demethylation pathways (Fig. 4). Although core DMRs are methylated (or not) in the germ line and these states are then inherited after fertilization, it should be pointed out that repeats could have a role in either establishment (in the germ line) or in maintenance of allelic methylation (in embryos), or in both processes.

There is precedent for the role of repeat sequences in gene silencing and possibly in inducing regional methylation. Hence, repeat-induced gene silencing has been observed in organisms as diverse as fungi, insects, plants, and mammals, in- cluding those in which there is no methylation (Trends Genet. 1997). A denovo methylation center has been identified in the mouse adenine phosphoribosyltransferase gene (aprt) that imparts a methylation signal to upstream and downstream $\mathrm{Hpall}$ sites (Mummaneni et al. 1993). The bulk of the methylation center signal seems to emanate from tandem B1 repetitive elements (Turker and Bestor 1997) and it has been postulated that Sp1-binding sites in the promoter region are necessary to stop the spreading of the de novo methylation (Mummaneni et al. 1995). Hypothetically, repeat elements may also function as recognition "nuclei" by protein complexes such as the methyltransferase, PCNA-p21-methyltransferase complexes, or even protein complexes involved in chromosomal repression, as in telomeric silencing mediated by RAP1SIR protein complexes in yeast (Moretti et al. 1994).

Some DM Rs acquire their al lelic methylation after fertilization. The local spacing and cooperativity between these DMRs and core DMRs (i.e., somatic

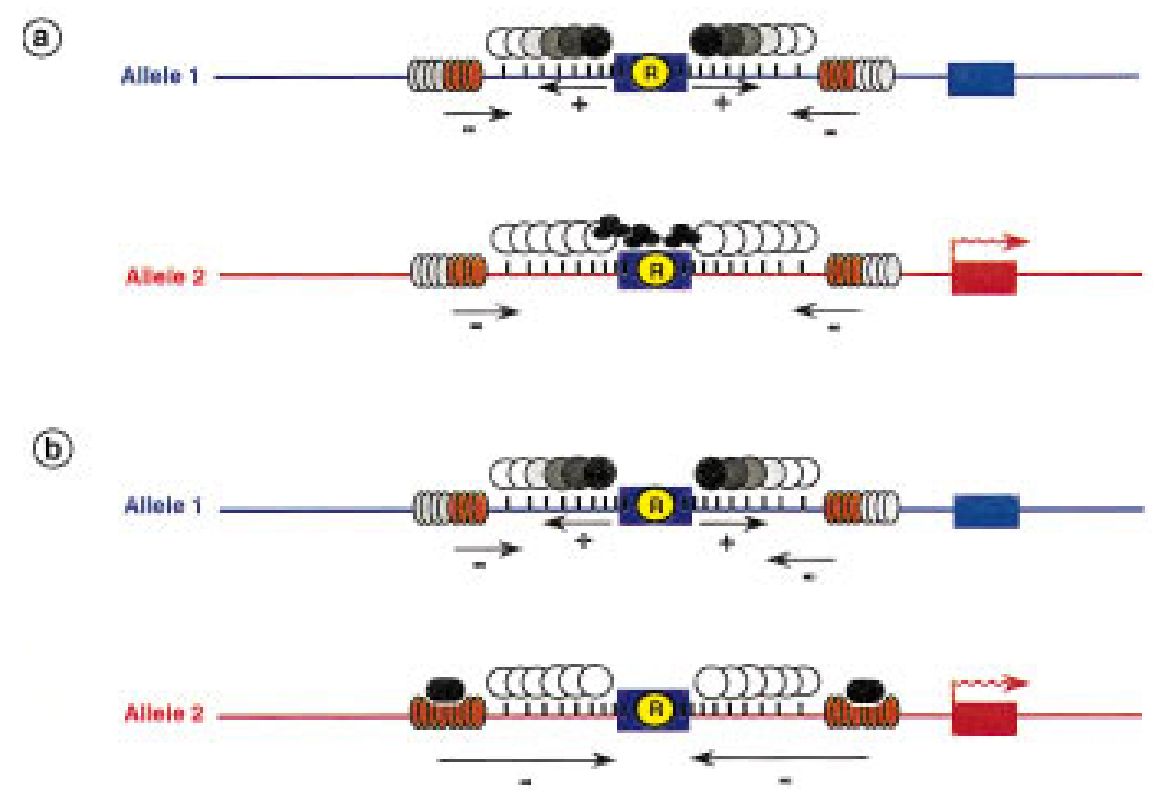

Figure 4 Hypothetical role for tandem repeats in the establishment of allelespecific methylation patterns at imprinted loci. These patterns are the result of the interaction of opposing positive $(+)$ methylation and negative $(-)$ demethylation signals. (a) The repeats (R) may act as methylation centers (see text), attracting or inducing the spread of methylation over a stretch of DNA (circles emanating from the repeat). The extent of methylation may be limited by counteracting demethylation signals (represented as gray/red disks) induced by CpG-rich environment (vertical bars). Trans-acting factors (trefoil structures) interfere with methylation or its spreading (allele 2) [a gradient of methylation is represented by differently shaded circles; (white circles) lack of methylation; (solid circles) complete methylation]. (b) Trans-acting factors (black ovals) may act alternatively in the demethylation pathway resulting in a dominant demethylation signal, spreading over the entire region (allele 2). 
and germ-line methylation imprints) may be important for the propagation of the imprinting signal and stabilization of specific epigenotypes in imprinting clusters (Reik and Walter 1998). The disruption of any of these elements could result in failure to maintain or establish a parental epigenotype.

RNAs, Competition, and Regional Control of Epigenotype

Transcripts originating from the noncoding or antisense strand, in a parental allele-specific manner, have been found in three imprinted genes so far. An antisense transcript (with no apparent ORF) is expressed abundantly from the paternal allele of Igf $2 r$, initiating within region 2 . This antisense is thought to be responsible for monoallelic expression of Igf $2 r$ by repressing specifically the paternal allele of Igf $2 r$ in cis (Wutz et al. 1997), an example of "expression competition" (Fig. 5a) in which the antisense is perceived as an "imprintor" and the Igf2r gene as its imprinted target (Barlow 1997). Deletion of the antisense promoter or enhancer leads to nonimprinted expression of Igf2r. Although no developmental details have yet been reported, it is conceivable that antisense expression coincides with the onset of monoallelic expression of Igf2r at E5-E6 (Lerchner and Barlow 1997). This would explain the lack of correlation between the onset of repression and promoter methylation (region 1) on the paternal allele (Stöger et al. 1993). Transcription could be repressed first by the antisense and then methyl-

\section{lgf2r/gf/2ras}
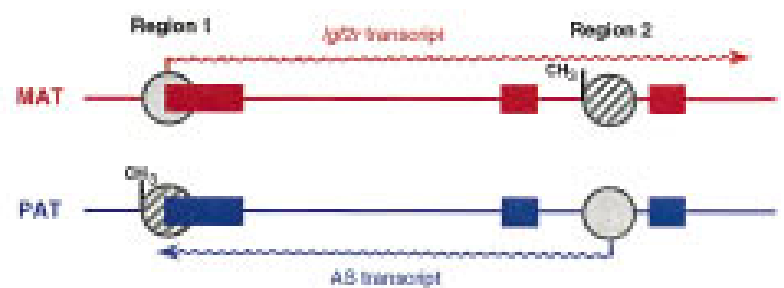

ation would "lock" the repressed state later in de vel opment. The antisense may repress the paternal I $\mathrm{gf} 2 \mathrm{r}$ allele in cis in several ways, such as physically coating the paternal allele (in a similar way to Xist; see bel ow), occlusion of the Igf $2 r$ promoter by transcribing through it in the opposite direction, or competition for transcription factors or enhancers (Reik and Constância 1997).

An imprinted antisense RNA has also been found to overlap the maternally expressed UBE3A gene and is thought to regulate tissue specificity of UBE3A imprinting (Rougeulle et al. 1998). The antisense RNA is expressed exclusively in the brain from the paternal chromosome, thus apparently limiting expression of the UBE3A gene to the maternal chromosome in this tissue. In other tissues, where the antisense RNA is not detectable, UBE3A is expressed biallelicaly (Rougeulle et al. 1998).

Several imprinted antisense transcripts (I gf2as$a, b$, and c) have been described in the upstream region of the Igf2 gene (Moore et al. 1997), but in contrast to Igf2 $r$ they are expressed from the same allele as Igf2 and at low levels. The role of these antisen se transcripts is unclear, but overlapping antisense transcription may influence the activity of promoters 0 and 1 , because of their proximity to these two regions, and regulate Igf 2 levels in a tissuespecific fashion.

$\mathrm{H} 19$ is an example of an imprinted, untranslated RNA involved, through enhancer competition, in regulating the closely linked but recipro-

Figure 5 Expression competition mechanisms at the lgf2r/lgf2 ras and lgf2/H19 loci. (a) Exons of Igf2 $r$ are depicted as solid boxes, with arrows indicating the transcribed alleles; regions 1 and 2 are sites of differential methylation (hatched circles with $\mathrm{CH}_{3}$ : methylation) arising during embryonic development and in the egg, respectively. When the antisense transcript (AS) is expressed, the sense (Igf2r) is not and vice versa. The methylation mark at region 2 may function by regulating a putative antisense promoter that competes with Igf2 $r$ for expression (Barlow 1997); (b) H19 and Igf2 genes are indicated as solid boxes. The downstream H19 endodermal-specific enhancers are represented by filled ovals. DMRs are represented by hatched circles; at the Igf2 gene the expressed allele is hypermethylated at two intronic regions (for simplification represented as a single region; there is also a maternally methylated region that is not shown here); methylation of the paternal H19 promoter blocks interaction with downstream enhancers on the paternal chromosome, which are then free to interact with the paternal Igf2 promoter (long arrow). Proper imprinting at the Igf2/H19 loci seems, therefore, to depend on promoter competition for the downstream H19 enhancers. 
cally imprinted genes Igf2 and Ins2 (Leighton et al. 1995a). The mechanism appears to be competition for shared enhancer elements located downstream of H19 (Bartolomei et al. 1993; Leighton et al. 1995b) (Fig. 5b). When the maternal H19 promoter is activated by the downstream enhancer, the Igf2 gene is not expressed from the maternal allele. $\mathrm{Pa}$ ternal expression of the Igf2 gene is observed when the enhancer is unable to interact with the $\mathrm{H} 19$ paternal promoter because it is methylated (Fig. 5). Proper imprinting of Igf 2 and $\mathrm{H} 19$ on the maternal chromosome seems to be dependent on the position of the enhancers relative to the two genes. Mice carrying an extra set of the $\mathrm{H} 19$ endoderm-specific enhancers between Igf 2 and $\mathrm{H} 19$ show expression of the normally silent Igf2 gene in liver, consistent with relief from competition (Webber et al. 1998). When a single set of enhancers is located equidistantly from Igf2 and $\mathrm{H} 19$ on the maternal chromosome, Igf2 is expressed instead of $\mathrm{H} 19$, suggesting that the strength of the H19 promoter is not the main determinant in the competition for enhancers (Webber et al. 1998). The core DMR associated with the $\mathrm{H} 19$ promoter may determine methylation of the $\mathrm{H} 19$ promoter but, in addition, may also play a role in allowing the $3^{\prime}$ enhancers access to the Igf2 promoters.

Unusual RNAs are also found in the upstream region of the SNRPN gene and may be involved in imprinting control for the entire PWS/AS region. Deletions and a splice mutation affecting these upstream transcripts are associated with AS, as they lead to an apparent failure to switch the paternal epigenotype in the maternal germ line (Dittrich et al. 1996). In contrast, deletion of the SNRPN CpG island region and promoter leads to an apparent inability to switch the maternal regional epigenotype in the paternal germ line, and hence to PWS. However, these observations could also be explained by extending the expression or enhancer competition model to the PWS/AS situation (Barlow 1997; Tilghman et al. 1998). Promoter competition between the SNRPN and UBE3A genes for a neuronal enhancer has been proposed recently (Tilghman et al. 1998). Methylation inactivating the SNRPN promoter on the maternal chromosome would lead to activation of the UBE3A gene.

A common feature of the enhancer competition model is that deletion of DMRs, promoter, or enhancers would imbalance the competition system. However, this model does not explain how regional methylation can be altered by DMR or promoter deletions (Sutcliffe et al. 1994; Buiting et al. 1995; Forné et al. 1997; Moore et al. 1997; Wutz et al.
1997). It has been suggested that cis-acting RNAs that interact with DMRs could be involved in this regional spreading (Reik and Walter 1998).

A precedent for the role of an untranslated RNA in regional silencing in cis is the $X$ ist gene. The $X$ ist RNA is expressed from the inactive $X$ chromosome in female mammals and is essential for inactivation of genes along the $X$ chromosome (Penny et al. 1996; Marahrens et al. 1997). The accumulation of $X$ ist transcripts along the length of the inactive chromosome (Clemson et al. 1996; Lee and Jaenisch 1997 ) is thought to be required for the nucleation and spread of heterochromatin from the $X$ inactivation center (Xic) (Panning et al. 1997). Inactivation of the paternal $X$ chromosome occurs in extraembryonic tissues and consistent with this the paternal Xist copy is expressed preferentially in female preimplantation embryos (Kay et al. 1993). However, in embryonic lineages, in which $X$ inactivation is random, the imprinted expression needs to be reprogrammed. This may involve expression of unstable Xist transcripts from both $X$ chromosomes (Panning et al. 1997; Sheardown et al. 1997), which could be brought about by using alternative promoters (Sheardown et al. 1997). The future inactive $X$ chromosome then stabilizes Xist RNA by an unknown mechanism (possibly involving a promoter switch), whereas the active $X$ chromosome fails to accumulate Xist. This initial decision is "locked" by subsequent silencing of $X i s t$, at the transcriptional level, on the active $X$ chromosome by DNA methylation (Panning and Jaenisch 1996; Panning et al. 1997).

\section{Reading the Imprint}

The different methylation states of the two alleles have to be translated into monoallelic expression. This is termed the reading of the imprint. The reading mechanism requires the involvement of various trans-acting factors, some of which can detect the methylation status of the DNA environment and some of which interact with these factors to control the transcriptional competence of the particular allele. Methylation, although of key importance to the imprinting process, is involved primarily in the general control of gene expression. The typical observation is that methylating a gene results in its silencing. In fact, the majority of CPG dinucleotides in the mammalian genome are methylated; this has been suggested to be the default state required to shut down unwanted and potentially harmful transcriptional noise (Bird 1995), including that of the transposable element-based repeats scattered 
throughout the genome (Yoder et al. 1997a). Hence, unmethylated regions are relatively rare and usually encountered in the form of $\mathrm{CpG}$ islands associated with the promoters of expressed housekeeping genes (Bird 1995). If such regions become erroneously methylated (for example, in tumors) then the associated gene is repressed. This is the case for the CpG islands of tumor suppressors VHL, p16, and Rb (Laird and Jaenisch 1996). Certain transgenes also show a tight inverse correlation between methylation levels and expression (Allen et al. 1990; Chaillet et al. 1991).

Is it possible to treat monoallelic expression through imprinting as just a special case of methylation silencing? It could be postulated that the "hard work" of distinguishing the two parental alIeles has al ready been accomplished by the imposition of the differential methylation pattern. The next step is the "blind" transcriptional response to the methylation pattern, which only requires the factors responsible for the initiation or inhibition of transcription to associate with the appropriate allele. This would be determined not only by the availability of the appropriate transcription factors for the enhancer/promoter elements, but also how these transcription factors respond to the methylation patterns that may exist in those regions.

Reading Factors

DNA-binding factors can respond in a number of ways to the methylation of their target sites. Some seem relatively unaffected by the methylation status of their binding sites (Tate and Bird 1993). These include Sp1, MTF-1, Krox-20, CTF/NF1, and TCRATF. Table 1 lists those factors whose binding affinities are altered by the methylation of their target sequences and Figure 6 illustrates the potential effects of methylation on trans-acting factor binding and subsequent transcriptional control.

The silencing of transcription brought about by methylation has been divided into two categories: (1) that resulting from the inability of methylationsensitive transcription factors to bind to their target sequences and contribute to gene activation, and (2) that resulting from the binding of methylationdependent silencer proteins that may act by nucleating chromatin structures in the gene region. The $X$ ist gene possesses a transcription-promoting element that binds factors belonging to both of these categories (Huntriss et al. 1997). When unmethylated, a factor binds and may activate expression of the gene. However, with methylation, the activator is no longer able to bind and is replaced by a meth- ylation-dependent binding protein that may act to silence gene expression.

Two proteins of the second category, MeCP1 and MeCP2, appear to be crucial in general methylation-dependent silencing. MeCP2 is an abundant protein that possesses domains that bind methylated DNA and repress transcription (probably indirectly). Immunofluorescence studies show that the MeCP2 protein is tightly associated with chromosomes, especially in heterochromatic regions (Nan et al. 1997). Interestingly, M CCP2 may carry out part of its inhibitory role by becoming a key part of the chromatin complex itself as it has been shown that $\mathrm{MeCP} 2$ can replace the linker histone $\mathrm{H} 1$ in the compacted DNA of silenced regions. MeCP1 is a complex of several proteins including one, PCM1, which has a methyl-binding domain homologous to $\mathrm{MeCP} 2$ and a cysteinerich domain homologous to those found in the DNMT1 and HRX proteins (Cross et al. 1997). The complex is widely expressed at a low level and requires a greater density of methylated cytosines than does MeCP2 before binding occurs. Binding of MeCPs to methylated DNA results in reduced accessibility of chromatin to endonucleases (DNasel, restriction enzymes). Consistent with an involvement of such proteins in allelic silencing, some imprinted genes show markedly reduced DNase accessibility in regions of extensive methylation (Bartolomei et al. 1993; FergusonSmith et al. 1993; Feil and Kelsey 1997; Feil et al. 1997). However, the link between such proteins and the establishment of silencing through the formation of specific chromatin structures is still unknown (Kass et al. 1997). A key process may be the balancing act between the acetylation and deacetylation of histones within nucleosomes (Pazin and Kadonaga 1997). Deacetylation of these proteins, carried out by "histone deacetylases" (in mammals there are two, HD1 and HD2) in conjunction with another protein, $\operatorname{Sin} 3$, is associated with the silencing of genes such as Xenopus TR $\beta A$ (Wong et al. 1998). It has been suggested that the specificity of the deacetylation process may be dictated by DNAbound factors that serve to anchor the activity in appropriate areas. Indeed, it has been shown recently that M ECP-dependent silencing acts through deacetylation of histones (Jones et al. 1998; Nan et al. 1998).

In terms of imprinting, a recent paper has described the use of trichostatin A, a specific inhibitor of histone deacetylase, to examine the developmental onset of silencing of the paternal $\mathrm{H} 19$ allele in mouse trophectodermal cells (Svensson et al. 1998). Previous work had shown that there are variable 
Table 1. Methylation-Sensitive and -Dependent DNA-Binding Proteins and their Putative Functions

\begin{tabular}{|c|c|c|c|c|c|}
\hline $\begin{array}{l}\text { DNA-binding } \\
\text { factor }\end{array}$ & $\begin{array}{c}\text { Effect of } \\
\text { methylation } \\
\text { of target } \\
\text { sequence } \\
\text { (binding) }\end{array}$ & $\begin{array}{c}\text { Factor mol. } \\
\text { weight }\end{array}$ & Target sequence & Comments & Reference \\
\hline $\begin{array}{l}\text { Myc/Myn } \\
\text { CREB/ATF } \\
\text { NFKB } \\
\text { AP-2 } \\
\text { MLTF/USF } \\
\text { EBP-80 } \\
\text { VBP1 }\end{array}$ & inhibits & N.A. & N.A. & $\begin{array}{l}\text { a selection of general } \\
\text { transcription } \\
\text { factors with } \\
\text { binding inhibited } \\
\text { by methylation }\end{array}$ & $\begin{array}{l}\text { Tate and Bird } \\
\text { (1993) }\end{array}$ \\
\hline $\begin{array}{l}\text { Xist promoter } \\
\text { BP1 }\end{array}$ & inhibits & unknown & GCGCCGCGG & $\begin{array}{l}\text { putative factor } \\
\text { that binds } \\
\text { unmethylated } \\
\text { sequence upstream } \\
\text { of Xist transcription } \\
\text { start site and has a } \\
\text { positive effect on } \\
\text { expression (see Xist } \\
\text { promoter BP2 } \\
\text { below) }\end{array}$ & $\begin{array}{l}\text { Huntriss et al. } \\
\text { (1997) }\end{array}$ \\
\hline AP-1 & permits & N.A. & TGACTCG & $\begin{array}{l}\text { methylation of the } \\
\text { X-sequence in the } \\
\text { first exon of the } \\
\text { metastasis- } \\
\text { associated gene } \\
\text { mts-1 induces } \\
\text { Fos/Jun binding } \\
\text { resulting in } \\
\text { transcriptional } \\
\text { silencing }\end{array}$ & $\begin{array}{l}\text { Tulchinsky et al. } \\
\text { (1996) }\end{array}$ \\
\hline $\begin{array}{l}\text { MMBP-1 } \\
\text { MMBP-2 } \\
\text { MMBP-3 }\end{array}$ & $\begin{array}{l}\text { permits } \\
\text { permits } \\
\text { permits }\end{array}$ & $\begin{array}{l}42 \mathrm{kD} \\
63 \mathrm{kD} \\
50-60 \mathrm{kD}\end{array}$ & CACGTG & $\begin{array}{l}\text { three factors isolated } \\
\text { from C2C12 cells } \\
\text { that bind the } \\
\text { methylated form of } \\
\text { the c-Myc binding } \\
\text { site (expressed } \\
\text { only in actively } \\
\text { proliferating cells) }\end{array}$ & $\begin{array}{c}\text { Suetake et al. } \\
(1993 / 95)\end{array}$ \\
\hline DBPm & permits & $50 \mathrm{kD}$ & 35-mer (see Ref.) & $\begin{array}{l}\text { isolated from pea } \\
\text { seed. Plant } \\
\text { methylation plays } \\
\text { roles in } \\
\text { transposable } \\
\text { element silencing } \\
\text { and general } \\
\text { control of } \\
\text { development and } \\
\text { flowering }\end{array}$ & $\begin{array}{l}\text { Ehrlich et al. } \\
\text { (1993) }\end{array}$ \\
\hline
\end{tabular}


Table 1. (Continued)

\begin{tabular}{|c|c|c|c|c|c|}
\hline $\begin{array}{l}\text { DNA-binding } \\
\text { Factor }\end{array}$ & $\begin{array}{l}\text { Effect of } \\
\text { methylation } \\
\text { of target } \\
\text { sequence } \\
\text { (binding) }\end{array}$ & $\begin{array}{l}\text { Factor mol. } \\
\text { weight }\end{array}$ & Target sequence & Comments & Reference \\
\hline $\begin{array}{l}\text { Xist promoter } \\
\text { BP2 }\end{array}$ & permits & $100 \mathrm{kD}$ & GCGCCGCGG & $\begin{array}{l}\text { when methylated the } \\
\text { target sequence binds } \\
\text { this transcriptional } \\
\text { silencer, replacing } \\
\text { (outcompeting?) the } \\
\text { Xist promoter BP1 } \\
\text { described above }\end{array}$ & $\begin{array}{l}\text { Huntriss et al. } \\
\text { (1997) }\end{array}$ \\
\hline HMBP & permits & $\begin{array}{l}\text { 300-kD } \\
\text { complex }\end{array}$ & 43-mer (see Ref.) & $\begin{array}{l}\text { methylation of } 3 \\
\text { SP1-like sites in the } 5^{\prime} \\
\text { LTR of HIV can lower } \\
\text { expression of the } \\
\text { viral-encoded genes } \\
\text { (role in AIDS } \\
\text { latency?); HMBP, } \\
\text { expressed in T } \\
\text { lymphocytes, is } \\
\text { thought to participate } \\
\text { in this inhibition as it } \\
\text { only binds the } \\
\text { methylated target site }\end{array}$ & $\begin{array}{l}\text { Joel et al. } \\
\text { (1993) }\end{array}$ \\
\hline $\begin{array}{c}\text { RFX1, 2, } \\
\text { and } 3\end{array}$ & permits & $\begin{array}{c}2 \times 105-k D \\
\text { complex }\end{array}$ & GCCGTCATGGCGCC & $\begin{array}{l}\text { (also known as EF-C, } \\
\text { MDBP, NF-X, etc), } \\
\text { family of } 5+ \\
\text { conserved DNA } \\
\text { binding proteins. } \\
\text { Involved in MHCll } \\
\text { and viral gene } \\
\text { expression. RFX1, 2, } \\
\text { and } 3 \text { shown to } \\
\text { prefer some target sites } \\
\text { when methylated; } \\
\text { transcriptional } \\
\text { activators }\end{array}$ & $\begin{array}{l}\text { Zhang et al. } \\
\text { (1993) } \\
\text { Emery et al. } \\
\text { (1996) }\end{array}$ \\
\hline MDBP-2-H1 & permits & $47 \mathrm{kD}$ & methylated DNA & $\begin{array}{l}\text { member of the histone } \\
\text { H1 family found in } \\
\text { avian liver; preference } \\
\text { for association with } \\
\text { methylated DNA; } \\
\text { shown to be } \\
\text { truncated form of } \\
\text { normal H1; general } \\
\text { significance unknown }\end{array}$ & $\begin{array}{l}\text { Schwarz et al. } \\
\text { (1977) }\end{array}$ \\
\hline MeCP1 & permits & $\begin{array}{c}400 / 800 \\
k D\end{array}$ & several methyl-CpGs & $\begin{array}{l}\mathrm{PCM} 1(36 / 80 \mathrm{kD}) \text { is a } \\
\text { constituent of this } \\
\text { large complex }\end{array}$ & $\begin{array}{c}\text { Cross et al. } \\
\text { (1997) }\end{array}$ \\
\hline MeCP2 & permits & $80 \mathrm{kD}$ & 2 methyl-CpGs & $\begin{array}{l}\text { abundant but } \\
\text { insufficient in quantity } \\
\text { to bind to all genome's } \\
\text { methylated CpGs }\end{array}$ & $\begin{array}{l}\text { Nan et al. } \\
\text { (1997) }\end{array}$ \\
\hline
\end{tabular}


CONSTÂNCIAETAL.

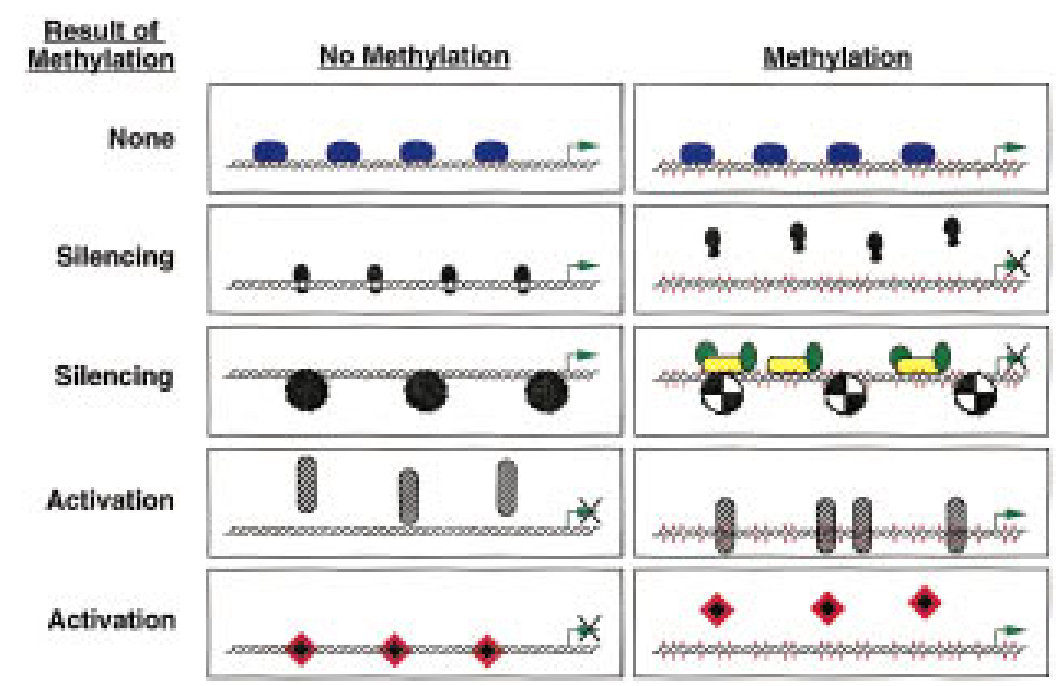

Figure 6 Four mechanisms by which methylation can alter transcription. Methylation may have no effect on expression (top). Methylationsensitive transcription factors cannot activate a methylated promoter (second pair of panels). Transcriptionally competent promoters with nucleosomes (dark circles) can acquire a protein complex with methylation (third pair of panels). This may include MeCPs and deacetylases, which alter nucleosome function (as shown by quartered circles) resulting in silencing. Some transcription factors require their target sites to be methylated before they can bind and promote gene expression (fourth pair of panels). A hypothetical situation where a repressor is dislodged by methylation (bottom). The last two models could explain the instances of expression from methylated alleles (see text).

amounts of biallelic H19 expression in early embryos. The drug treatment slowed the rate of paternal allele silencing, which resulted in increased numbers of patches of biallelic $\mathrm{H} 19$ expression beyond the normal stages. From these results we can conclude that the presence of biallelic expression from imprinted genes early in development may be the result of the immaturity of the silencing complex as well as the unrefined nature of the methylation pattern. Other routes to heterochromatization exist that do not require changes in histone acetylation. The polycomb group of genes has been shown to play important chromatin-mediated silencing effects in Drosophila (position effect variegation) and the regulation of mammalian genes such as the Hox clusters (Pirrotta 1997). The full repertoire of chromatin or chromatin-organizing genes potentially involved in the control of monoallelic expression remains to be cataloged.

The two categories of silencing described above are a useful guide but cannot explain all observations. For example, the actively transcribed paternal al lele of the Igf2 gene is the al lele that shows higher methylation levels (at DM R1 and DMR2). Assuming that these regions play an important role in the con- trol of monoallelic expression, it becomes necessary to explain this apparent reversal in the effect of methylation on transcription. It could be proposed that either a methylation-dependent activator protein is binding to the paternal DMRs (acting in the same way as RFX 1/RFX2/RFX3), or that a methylation-sensitive silencer protein is associated with the repressed maternal allele.

\section{Reading Disorders}

This review has al ready mentioned diseases arising from the loss of the correct imprint or from the failure to switch the imprint to reflect the parental origin. Is it possible that there exist defects in the reading process that have pathological consequences? Targeted disruption of the methyl-cytosine-binding protein gene MeCP2 has an early embryonic lethal phenotype leading to speculation that this is a critical component in the conversion of methylation into silencing that cannot be replaced by compensatory or parallel pathways (Tate et al. 1996). It will be interesting to determine whether expression of imprinted genes is altered in these knock-out mice. Are there less severe phenotypes arising from other reading machinery defects? There are several instances when a seemingly allelespecific methylation pattern is not translated into genuine monoallelic expression. This is the case for the human Igf $2 r$ gene where only some individuals (genotypes) show monoallelic expression. A possible cause of this variability could be that functional polymorphisms are present in the human genes responsible for the reading of the imprint as opposed to functional alterations in the imprint itself.

\section{Conclusions}

Major reprogramming of the imprints occurs in the germ lines of developing embryos. Both sex germ cells undergo global demethylation including imprinted and nonimprinted genes. The bulk of this demethylation probably occurs between E8.5 and E12.5. Functional studies on germ cells from this stage in chimeras or nuclear transplantations show that this demethylation is indeed associated with substantial reprogramming of imprinted genes. It is not yet clear whether all imprinted genes undergo 
complete reprogramming. New methylation imprints are established in the female germ line during oocyte growth after birth, and in males probably around the time of birth. In addition to germ-linespecific de novo methylation, protection from methylation may also be required.

Regions of differential methylation have been identified at all imprinted genes. Their developmental kinetics appear to be diverse and complex, some being stable and potentially associated with gametic imprinting signals, others arising later in development and more likely to be involved in maintenance of imprinting or spreading of an imprinted epigenotype in a cluster of imprinted genes. Genome-wide alterations in methylation occur in the preimplantation and early postimplantation embryo. However, methylation of core DMR regions of imprinted genes remains unaffected. This requires protective mechanisms that not only prevent the methylated allele from becoming demethylated but al so prevent the demethylated allele from de novo methylation. High methylation densities may play a role by causing resistance to demethylation. Multiple cis-acting sequences are probably required for the creation and maintenance of the methylation state. The precise methylation patterns are elaborated during postimplantation development.

Diverse sequence and structural motifs are associated with imprinted genes. DMRs are CpG-rich and associated with direct repeats; although this association with imprinted loci is strong, evidence for a functional role is, at present, inconclusive. One model for control of methylation at imprinted loci may involve the interplay between de novo methylation caused by repeats and demethylation induced by the CpG-rich environment. Other regulation mechanisms such as antisense transcription and enhancer competition play an important role in the imprinting process, probably both in individual genes and in imprinting clusters.

The mechanisms underlying the translation of the imprint into monoallelic gene expression are largely unknown. The methylated allele of most imprinted genes is the inactive one. Repression could be brought about by the inability of transcription factors to bind or alternatively, by the binding of MeCPs and associated silencing factors. Expression from the methylated allele is rare but may involve the displacement of repressors or the binding of methylation-dependent activating factors.

\section{A CKNO WLEDG MENTS}

We apologize to authors whose work could not be cited be- cause of space limitations. We thank M. Bartolomei, T. Bestor, J. Chaillet, H. Sasaki, A. Surani, and T. Kono for communicating unpublished results, and members of the laboratories of W. Reik and G. Kelsey for helpful discussions. Work in our laboratory is supported by Biotechnology and Biological Sciences Research Council, European Union, Medical Research Council, and Cancer Research Campaign. M.C. acknowledges support by a JNICT/PRAXIS XXI Scholarship (Portugal).

\section{REFEREN CES}

Albrecht, U., J.S. Sutcliffe, B.M. Cattanach, C.V. Beechey, D. Armstrong, G. Eichele, and A.L. Beaudet. 1997. Imprinted expression of the murine Angel man syndrome gene Ube3a in hippocampal and Purkinje neurons. Nature Genet. 17: 75-78.

Allen, N.D., M.L. Norris, and M.A. Surani. 1990. Epigenetic control of transgene expression and imprinting by genotype specific modifiers. Cell 61: 853-861.

Ariel, M., E. Robinson, J.R. McCarrey, and H. Cedar. 1995. Gamete-specific methylation correlates with imprinting of the murine Xist gene. Nature Genet. 9: 312-315.

Barlow, D.P. 1993. Methylation and imprinting: From host defense to gene regulation? Science 260: 309-310.

1997. Competition-a common motif for the imprinting mechanism? EMBO J. 16: 6899-6905.

Bartolomei, M.S., A.L. Webber, M.E. Brunkow, and S.M. Tilghman. 1993. Epigenetic mechanisms underlying the imprinting of the mouse $\mathrm{H} 19$ gene. Genes \& Dev. 7: 1663-1673.

Bird, A.P. 1995. Gene number, noise reduction and biological complexity. Trends Genet. 11: 94-100.

Brandeis, M., T. Kafri, M. Ariel, J.R. Chaillet, J. McCarrey, A. Razin, and H. Cedar. 1993. The ontogeny of allele-specific methylation associated with imprinted genes in the mouse. EMBO J. 12: 3669-3677.

Brandeis, M., D. Frank, I. Keshet, Z. Siegfried, M. Mendelsohn, A. Nemes, V. Temper, A. Razin, and H. Cedar. 1994. Sp1 elements protect a CpG island from de novo methylation. Nature 371: 435-438.

Buehr, M. 1997. The primordial germ cells of mammals: Some current perspectives. Exp. Cell Res. 232: 194-207.

Buiting, K., S. Saitoh, S. Gross, B. Dittrich, S. Schwartz, R.D. Nicholls, and B. Horsthemke. 1995. Inherited microdeletions in the Angelman and Prader-Willi syndromes define an imprinting centre on human chromosome 15. Nature Genet. 9: 395-400.

Carlson, L.L., A.W. Page, and T.H. Bestor. 1992. Properties and localization of DNA methyltransferase in preimplantation mouse embryos: Implications for genomic imprinting. Genes \& Dev. 6: 2536-2541. 
Chaillet, J.R., T.F. Vogt, D.R. Beier, and P. Leder. 1991. Parental-specific methylation of an imprinted transgene is established during gametogenesis and progressively changes during embryogenesis. Cell 66: 77-83.

Chaillet, J.R., D.S. Bader, and P. Leder. 1995. Regulation of genomic imprinting by gametic and embryonic processes. Genes \& Dev. 9: 1177-1187.

Chesnokov, I.N. and C.W. Schmid. 1995. Specific Alu binding protein from human sperm chromatin prevents DNA methylation. J. Biol. Chem. 270: 18539-18542.

Clemson, C.M., J.A. McNeil, H.F. Willard, and J.B. Lawrence. 1996. Xist RNA paints the inactive $X$ chromosome at interphase: Evidence for a novel RNA involved in nuclear/chromosome structure. J. Cell. Biol. 132: $259-275$.

Cross, S.H., R.H. Meehan, X. Nan, and A. Bird. 1997. A component of the transcriptional repressor $\mathrm{MeCP} 1$ shares a motif with DNA methyltransferase and HRX proteins. Nature Genet. 16: 256-259.

Dittrich, B., K. Buiting, B. Korn, S. Rickard, J. Buxton, S. Saitoh, R.D. Nicholls, A. Poustka, A. Winterpacht, B. Zabel, and B. Horsthemke. 1996. Imprint switching on human chromosome 15 may involve alternative transcripts of the SNRPN gene. Nature Genet. 14: 163-170.

Ehrlich, K.C. 1993. Partial purification of a pea seed DNA-binding protein that specifically recognizes 5-methylcytosine. Prep. Biochem. 23: 423-438.

Elson, D.A. and M. Bartolomei. 1997. A 5' differentially methylated sequence and the $3^{\prime}$-flanking region are necessary for $\mathrm{H} 19$ transgene imprinting. Mol. Cell. Biol. 17: 309-317.

Emery, P., B. Durand, B. Mach, and W. Reith. 1996. RFX proteins, a novel family of DNA binding proteins conserved in the eukaryotic kingdom. Nucleic Acids Res. 24: 803-807.

Eversole-Cire, P., A.C. Ferguson-Smith, H. Sasaki, K.D. Brown, B.M. Cattanach, F.A. Gonzales, M.A. Surani, and P.A. Jones. 1993. Activation of an imprinted Igf2 gene in mouse somatic cell cultures. Mol. Cell. Biol. 13: 4928-4938.

Feil, R. and G. Kelsey. 1997. Genomic imprinting: A chromatin connection. Am. J. Hum. Genet. 61: 1213-1219.

Feil, R., J. Walter, N.D. Allen, and W. Reik. 1994. Developmental control of allelic methylation in the imprinted mouse Igf2 and $\mathrm{H} 19$ genes. Development 120: 2933-2943.

Feil, R., M.D. Boyano, N.D. Allen, and G. Kelsey. 1997. Parental chromosome-specific chromatin conformation in the imprinted U2af1-rs1 gene in the mouse. J. Biol. Chem. 272: 20893-20900.

Ferguson-Smith, A.C., H. Sasaki, B.M. Cattanach, and M.A. Surani. 1993. Parental-origin-specific epigenetic modification of the mouse H19 gene. Nature 362: 751-755.
Forné, T., J. Oswald, W. Dean, J.R. Saam, B. Bailleul, L. Dandolo, S.M. Tilghman, J. Walter, and W. Reik. 1997. Loss of the maternal $\mathrm{H} 19$ gene induces changes in Igf2 methylation in both cis and trans. Proc. Natl. Acad. Sci. 94: 10243-10248.

Horsthemke, B. 1997. Imprinting in the Prader-Willi/Angelman syndrome region on human chromosome 15. In Frontiers in molecular biology (series ed. B.D. Hames and D.M. Glover); Genomic imprinting (ed. W. Reik and A. Surani), pp. 177-190. IRL Press, Oxford, UK.

Horsthemke, B., B. Dittrich, and K. Buiting. 1997. Imprinting mutations on human chromosome 15. Hum. Mutat. 10: 329-337.

Howell, C.Y., A.L. Steptoe, M.W. Miller, and J.R. Chaillet. 1998. Cis-acting signal for inheritance of imprinted DNA methylation patterns in the preimplantation mouse embryo. Mol. Cell. Biol. 18: 4147-4156.

Howlett, S.K. and W. Reik. 1991. Methylation levels of maternal and paternal genomes during preimplantation development. Development 113: 119-127.

Huntriss, J., R. Lorenzi, A. Purewal, and M. Monk. 1997. A methylation-dependent DNA-binding activity recognising the methylated promoter region of the mouse $\mathrm{X}$ ist gene. Biochem. Biophys. Res. Commun. 235: 730-738.

Jähner, D. and R. Jaenisch. 1984. DNA methylation in early mammalian development. In DNA methylation: Biochemistry and biological significance (ed. A. Razin, H. Cedar, and A.D. Riggs), pp. 189-219. Springer-Verlag, New York, NY.

Jinno, Y., K. Sengoku, M. Nakao, K. Tamate, T. Miyamoto, T. Matsuzaka, J.S. Sutcliffe, T. Anan, N. Takuma, K. Nishiwaki, Y. Ikeda, T. Ishimaru, M. Ishikawa, and N. Niikawa. 1996. Mouse/human sequence divergence in a region with a paternal-specific methylation imprint at the human H19 locus. Hum. Mol. Genet. 5: 1155-1161.

Joel, P., W. Shao, and K. Pratt. 1993. A nuclear protein with enhanced binding to methylated Spl sites in the AIDS virus promoter. Nucleic Acids Res. 21: 5786-5793.

Jones, P.L., G.J.C. Veenstra, P.A. Wade, D. Vermaak, S.U. Kass, N. Landsberger, J. Strouboulis, and A.P. Wolffe. 1998. Methylated DNA and MeCP2 recruit histone deacetylase to repress transcription. Nature Genet. 19: 187-191.

Kafri, T., M. Ariel, M. Brandeis, R. Shemer, L. Urven, J. McCarrey, H. Cedar, and A. Razin. 1992. Developmental pattern of gene-specific DNA methylation in the mouse embryo and germ line. Genes \& Dev. 6: 705-714.

Kafri, T., X. Gao, and A. Razin. 1993. Mechanistic aspects of genome-wide demethylation in the preimplantation mouse embryos. Proc. Natl. Acad. Sci. 90: 10558-10562.

Kass, S.U., D. Pruss, and A.P. Wolffe. 1997. How does DNA methylation repress transcription? Trends Genet.

13: 444-449. 
Kato, Y. and Y. Tsunoda. 1995. Germ-cell nuclei of male fetal mice can support development of chimeras to mid-gestation following serial transplantation. Development 121: $779-783$.

Kay, G.F., G.D. Penny, D. Patel, A. Ashworth, N. Brockdorff, and S. Rastan. 1993. Expression of Xist during mouse development suggests a role in the initiation of $\mathrm{X}$-chromosome inactivation. Cell 72: 171-182.

Kelsey, G. and W. Reik. 1997. Imprint switch mechanism indicated by mutations in Prader-Willi and Angelman syndromes. Bioessays 19: 361-365.

Koide, T., J. Ainscough, M. Wijgerde, and M.A. Surani. 1994. Comparative analysis of Igf-2/H19 imprinted domain: Identification of a highly conserved intergenic DNasel hypersensitive region. Genomics 24: 1-8.

Kono, T., Y. Obata, T. Yoshimzu, T. Nakahara, and J. Carroll. 1996. Epigenetic modifications during oocyte growth correlate with extended parthenogenetic development in the mouse. Nature Genet. 13: 91-94.

Labosky, P.A., D.P. Barlow, and B.L.M. Hogan. 1994. Mouse embryonic germ (EG) cell-lines-transmission through the germline and differences in the methylation imprint of insulin-like growth-factor 2 receptor (IGF2R) gene compared with embryonic stem (ES) cell lines. Development

120: 3197-3204.

Laird, P.W. and R. Jaenisch. 1996. The role of DNA methylation in cancer genetics and epigenetics. Annu. Rev. Gen. 30: 441-464.

Lee, J.T. and R. Jaenisch. 1997. Long-range cis effects of ectopic $X$-inactivation centres on a mouse autosome. Nature 386: $275-279$.

Lei, H., S.P. Oh, M. Okano, R. Juttermann, K.A. Goss, R. Jaenisch, and E. Li. 1996. De novo DNA cytosine methyltransferase activities in mouse embryonic stem cells. Development 122: 3195-3205.

Leighton, P.A., R.S. Ingram, J. Eggenschwiler, A. Efstratiadis, and S.M. Tilghman. 1995a. Disruption of imprinting caused by deletion of the $\mathrm{H} 19$ gene region in mice. Nature 375: 34-39.

Leighton, P.A., J.R. Saam, R.S. Ingram, C.L. Stewart, and S.M. Tilghman. 1995b. An enhancer deletion affects both H19 and Igf2 expression. Genes \& Dev. 9: 2079-2089.

Lerchner, W. and D.P. Barlow. 1997. Paternal repression of the imprinted mouse Igf $2 r$ locus occurs during implantation and is stable in all tissues of the post-implantation mouse embryo. Mech. Dev. 61: 141-149.

Li, E., T.H. Bestor, and R. Jaenisch. 1992. Targeted mutation of the DNA methyltransferase gene results in embryonic lethality. Cell 69: 915-926.

Li, E., C. Beard, and R. Jaenisch. 1993. Role of DNA methylation in genomic imprinting. Nature 366: 362-365.
Lyko, F., J.D. Brenton, M.A. Surani, and R. Paro. 1997. An imprinting element from the mouse $\mathrm{H} 19$ locus functions as a silencer in Drosophila. Nature Genet. 16: 171-173.

Macleod, D., J. Charlton, J. Mullins, and A.P. Bird. 1994. Sp1 sites in the mouse aprt gene promoter are required to prevent methylation of the CpG island. Genes \& Dev. 8: 2282-2292.

Marahrens, Y., B. Panning, J. Dausman, W. Strauss, and R. Jaenisch. 1997. Xist-deficient mice are defective in dosage compensation but not spermatogenesis. Genes \& Dev. 11: $156-166$.

Mertineit, C., J.A. Yoder, T. Taketo, D.W. Laird, J.M. Trasler, and T.H. Bestor. 1998. Sex-specific exons control DNA methyltransferase in mammalian germ cells. Development 125: 889-897.

Michaud, E.J., M.J. van Vugt, S.J. Bultman, H.O. Sweet, M.T. Davisson, and R.P. Woychik. 1994. Differential expression of a new dominant agouti allele ( $A^{\text {iapy }}$ ) is correlated with methylation state and is influenced by parental lineage. Genes \& Dev. 8: 1463-1472.

Monk, M., M. Boubelik, and S. Lehnert. 1987. Temporal and regional changes in DNA methylation in the embryonic, extraembryonic and germ cell lineages during mouse embryo development. Development 99: 371-382.

Moore, T., M. Constância, M. Zubair, B. Bailleul, R. Feil, H. Sasaki, and W. Reik. 1997. Multiple imprinted sense and antisense transcripts, differential methylation and tandem repeats in a putative imprinting control region upstream of mouse Igf2. Proc. Natl. Acad. Sci. 94: 12509-12514.

Moretti, P., K. Freeman, L. Coodly, and D. Shore. 1994. Evidence that a complex of SIR proteins interacts with the silencer and telomere-binding protein RAP1. Genes \& Dev. 8: 2257-2269.

Moulton, T., T. Crenshaw, H. Yao, J. Moosihasuwan, N. Lin, F. Dembitzer, T. Hensle, L. Weiss, L. McMorrow, T. Loew, W. Kraus, W. Gerald, and B. Tycko. 1994. Epigenetic lesions at the $\mathrm{H} 19$ locus in Wilms' tumour patients. Nature Genet. 7: $440-447$.

Mummaneni, P., P.L. Bishop, and M.S. Turker. 1993. A cis-acting element accounts for a conserved methylation pattern upstream of the mouse adenine phosphoribosyltransferase gene. J. Biol. Chem. 268: $552-558$.

Mummaneni, P., K.A. Walker, P.L. Bishop, and M.S. Turker. 1995. Epigenetic gene inactivation induced by a cis-acting methylation center. J. Biol. Chem. 270: 788-792.

Nan, X., J. Campoy, and A. Bird. 1997. MeCP2 is a transcriptional repressor with abundant binding sites in genomic chromatin. Cell 88: 471-481.

Nan, X., H.-H. Ng, C.A. Johnson, C.D. Laherty, B.M. Turner, R.N. Eisenman, and A. Bird. 1998. Transcriptional repression by the methyl-CpG-binding protein MeCP2 
involves a histone deacetylase complex. Nature 393: 386-389.

Neumann, B., P. Kubicka, and D.P. Barlow. 1995. Characteristics of imprinted genes. Nature Genet. 9: 12-13.

Obata, Y., T. Kaneko-Ishino, T. Koide, Y. Takai, T. Ueda, I. Domeki, T. Shiroishi, F. Ishino, and T. Kono. 1998. Disruption of primary imprinting during oocyte growth leads to the modified expression of imprinted genes during embryogenesis. Development 125: 1553-1560.

Olek, A. and J. Walter. 1997. The pre-implantation ontogeny of the $\mathrm{H} 19$ methylation imprint. Nature Genet. 17: $275-276$.

Panning, B. and R. Jaenisch. 1996. DNA hypomethylation can activate $X$ ist expression and silence $X$-linked genes. Genes \& Dev. 10: 1991-2002.

Panning, B., J. Dausman, and R. Jaenisch. 1997. X chromosome inactivation is mediated by $\mathrm{X}$ ist RNA stabilization. Cell 90: 907-916.

Pazin, M.J. and J.T. Kadonaga. 1997. What's up and down with histone deacetylation and transcription? Cell 89: $325-328$.

Penny, G.D., G.F. Kay, S.A. Sheardown, S. Rastan, and N. Brockdorff. 1996. Requirement for Xist in X chromosome inactivation. Nature 379: 131-137.

Pfeifer, K., P.A. Leighton, and S.M. Tilghman. 1996. The structural $\mathrm{H} 19$ gene is required for transgene imprinting. Proc. Natl. Acad. Sci. 93: 13876-13883.

Pirrotta, V. 1997. PcG complexes and chromatin silencing. Curr. Opin. Genet. Dev. 7: 249-258.

Razin, A. and R. Shemer. 1995. DNA methylation in early development. Hum. Mol. Genet. 4: 1751-1755.

Reik, W. and M. Constância. 1997. Genomic imprinting: Making sense or antisense? Nature 389: 669-671.

Reik, W. and J. Walter. 1998. Imprinting mechanisms in mammals. Curr. Opin. Genet. Dev. 8: 154-164.

Römer, I., W. Reik, W. Dean, and J. Klose. 1997. Epigenetic inheritance in the mouse. Curr. Biol. 7: 277-280.

Rossant, J. 1993. Immortal germ cells? Curr. Biol. 3: 47-49.

Rougeulle, C., C. Cardoso, M. Fontes, L. Colleaux, and M. Lalande. 1998. An imprinted antisense RNA overlaps UBE3A and a second maternally expressed transcript. Nature Genet. 19: 15-16.

Sanford, J.P., H.J. Clark, V.M. Chapman, and J. Rossant. 1987. Differences in DNA methylation during oogenesis and spermatogenesis and their persistence during early embryogenesis in the mouse. Genes \& Dev. 1: 1039-1046.

Sapienza, C., J. Paquette, T.H. Tran, and A. Peterson. 1989.
Epigenetic and genetic factors affect transgene methylation imprinting. Development 107: 155-168.

Sasaki, H., A.C. Ferguson-Smith, A.S.W. Shum, S.C. Barton, and M.A. Surani. 1995. Temporal and spatial regulation of H19 imprinting in normal and uniparental mouse embryos. Development 121: 4195-4202.

Sasaki, H., P.A. Jones, J.R. Chaillet, A.C. Ferguson-Smith, S.C. Barton, W. Reik, and M.A. Surani. 1992. Parental imprinting: Potentially active chromatin of the repressed maternal allele of the mouse insulin-like growth factor II (Igf2) gene. Genes \& Dev. 6: 1843-1856.

Schwarz, S., D. Hess, and J.-P. Jost. 1997. The methylated DNA binding protein-2-H1 (MDBP-2-H1) consists of histone $\mathrm{H} 1$ subtypes which are truncated at the $\mathrm{C}$-terminus. Nucleic Acids Res. 25: 5052-5056.

Sheardown, S.A., S.M. Duthie, C.M. Johnston, A.E.T. Newall, E.J. Formstone, R.M. Arkell, T.B. Nesterova, G.-C. Alghisi, S. Rastan, and N. Brockdorff. 1997. Stabilization of Xist RNA mediates initiation of $X$ chromosome inactivation. Cell 91: 99-107.

Shemer, R., Y. Birger, W.L. Dean, W. Reik, A.D. Riggs, and A. Razin. 1996. Dynamic methylation adjustment and counting as part of imprinting mechanisms. Proc. Natl. Acad. Sci. 93: 6371-6376.

Shemer, R., Y. Birger, A.D. Riggs, and A. Razin. 1997. Structure of the imprinted mouse Snrpn gene and establishment of its parental-specific methylation pattern. Proc. Natl. Acad. Sci. 94: 10267-10272.

Shibata, H., K. Yoshino, S. Sunahara, Y. Gondo, M. Katsuki, T. Ueda, M. Kamiya, M. Muramatsu, Y. Murakami, I. Kalcheva, C. Plass, V.M. Chapman, and Y. Hayashizaki. 1996. Inactive allele-specific methylation and chromatin structure of the imprinted gene U2af1-rs1 on chromosome 11. Genomics 35: 248-252.

Shibata, H., T. Ueda, M. Kamiya, A. Yoshiki, M. Kusakabe, C. Plass, W.A. Held, S. Sunahara, M. Katsuki, M. Muramatsu, and Y. Hayashizaki. 1997. An oocyte-specific methylation imprint center in the mouse U2afbp-rs/U2af1-rs1 gene marks the establishment of allele-specific methylation during preimplantation development. Genomics 44: 171-178.

Shibata, H., Y. Yoda, R. Kato, T. Ueda, M. Kamiya, N. Hiraiwa, A. Yoshiki, C. Plass, R.S. Pearsall, W.A. Held, M. Muramatsu, H. Sasaki, M. Kusakabe, and Y. Hayashizaki. 1998. A methylation imprint mark in mouse imprinted gene Grf1/Cdc25M m locus shares a common feature with U2afbp-rs gene: An association with a short tandem repeat and a hypermethylated region. Genomics 49: 30-37.

Smrzka, O.W., I. Faé, R. Stöger, R. Kurzbauer, G.F. Fisher, T. Henn, A. Weith, and D.P. Barlow. 1995. Conservation of a maternal-specific methylation signal at the human IGF2R locus. Hum. Mol. Genet. 4: 1945-1952.

Steenman, M.J.C., S. Rainier, C.J. Dobry, P. Grundy, I.L. 
Horon, and A.P. Feinberg. 1994. Loss of imprinting of IGF2 is linked to reduced expression and abnormal methylation of H19 in Wilms' tumour. Nature Genet. 7: 433-439.

Stöger, R., P. Kubicka, C.-G. Liu, T. Kafri, A. Razin, H. Cedar, and D.P. Barlow. 1993. Maternal-specific methylation of the imprinted mouse Igf2r locus identifies the expressed locus as carrying the imprinting signal. Cell 73: 61-71.

Suetake, I., S. Tajima, and A. Asano. 1993. Identification of two novel mouse nuclear proteins that bind selectively to a methylated c-Myc recognizing sequence. Nucleic Acids Res.

\section{1: 2125-2130.}

1995. A novel DNA binding protein that recognizes the methylated c-Myc binding motif. J. Biochem. 118: $244-249$.

Surani, M.A. 1998. Imprinting and the initiation of gene silencing in the germ line. Cell 93: 309-312.

Sutcliffe, J.S., M. Nakao, S. Christian, K.H. Orstavik, N. Tommerup, D.H. Ledbetter, and A.L. Beaudet. 1994. Deletions of a differentially methylated CpG island at the Snrpn gene define a putative imprinting control region. Nature Genet. 8: 52-58.

Svensson, K., R. Mattsson, T.C. James, P. Wentzel, M. Pilartz, J. MacLaughlin, S.J. Miller, T. Olsson, U.J. Eriksson, and R. Ohlsson. 1998. The paternal allele of the $\mathrm{H} 19$ gene is progressively silenced during early mouse development: The acetylation status of histones may be involved in the generation of variegated expression patterns. Development 125: $61-69$.

Szabo, P.E. and J.R. Mann. 1995. Biallelic expression of imprinted genes in the mouse germ line-implications for erasure, establishment, and mechanisms of genomic imprinting. Genes \& Dev. 9: 1857-1868.

Tada, M., T. Tada, L. Lefebvre, S.C. Barton, and M.A. Surani. 1997. Embryonic germ cells induce epigenetic reprogramming of somatic nucleus in hybrid cells. EMBO J. 16: $6510-6520$.

Tada, T., M. Tada, K. Hilton, S.C. Barton, T. Sado, N. Takagi, and M.A. Surani. 1998. Epigenotype switching of imprintable loci in embryonic germ cells. Dev. Genes Evol. 207: 551-561.

Tate, P.H. and A.P. Bird. 1993. Effects of DNA methylation on DNA-binding proteins and gene expression. Curr. Opin. Genet. Dev. 3: 226-231.

Tate, P., W. Skarnes, and A. Bird. 1996. The methyl-CpG binding protein $\mathrm{MeCP} 2$ is essential for embryonic development in the mouse. Nature Genet. 12: 205-208.

Tilghman, S.M., T. Caspary, and R.S. Ingram. 1998. Competitive edge at the imprinted Prader-Willi/Angelman region? Nature Genet. 18: 206-208.

Trasler, J.M., D.G. Trasler, T.H. Bestor, E. Li, and F. Ghibu.
1996. DNA methyltransferase in normal and $\mathrm{Dnmt}^{\mathrm{n}} / \mathrm{Dnmt} \mathrm{n}^{\mathrm{n}}$ mouse embryos. Dev. Dyn. 206: 239-247.

Tremblay, K.D., J.R. Saam, R.S. Ingram, S.M. Tilghman, and M.S. Bartolomei. 1995. A paternal-specific methylation imprint marks the alleles of the mouse $\mathrm{H} 19$ gene. Nature Genet. 9: 407-413.

Tremblay, K.D., K.L. Duran, and M.S. Bartolomei. 1997. A 5' 2-kilobase-pair region of the imprinted mouse $\mathrm{H} 19$ gene exhibits exclusive paternal methylation throughout development. Mol. Cell. Biol. 17: 4322-4329.

Trends Genet. 1997. Epigenetics: A special issue. 13: $293-341$.

Tucker, K.L., C. Beard, J. Dausman, L. Jackson-Grusby, P.W. Laird, H. Lei, E. Li, and R. Jaenisch. 1996. Germ line passage is required for establishment of methylation and expression patterns of imprinted but not of nonimprinted genes. Genes \& Dev. 10: 1008-1020.

Tulchinsky, E.M., G.P. Georgiev, and E.M. Lukanidin. 1996. Novel AP-1 binding site created by DNA-methylation. Oncogene 12: 1737-1745.

Turker, M.S. and T.H. Bestor. 1997. Formation of methylation patterns in the mammalian genome. Mut. Res. 386: $119-130$.

Ueda, T., K. Yamazaki, R. Suzuki, H. Fujimoto, H. Sasaki, Y. Sakaki, and T. Higashinakagawa. 1992. Parental methylation patterns of a transgenic locus in adult somatic tissues are imprinted during gametogenesis. Development 116: 831-839.

Ungaro, P., S. Casola, M. Vernucci, P.V. Pedone, C.B. Bruni, and A. Riccio. 1997. Relaxation of insulin-like growth factor-2 imprinting in rat cultured cells. Mol. Cell. Endocrinol. 135: 153-163.

Villar, A.J., E.M. Eddy, and R.A. Pedersen. 1995. Developmental regulation of genomic imprinting during gametogenesis. Dev. Biol. 172: 264-271.

Webber, A.L., R.S. Ingram, J.M. Levorse, and S.M. Tilghman. 1998. Location of enhancers is essential for the imprinting of $\mathrm{H} 19$ and Igf2 genes. Nature 391: 711-715.

Weiss, A., I. Keshet, A. Razin, and H. Cedar. 1996. DNA demethylation in vitro-involvement of RNA. Cell 86: 709-718.

Williamson, C.M., J. Schofield, E.R. Dutton, C.V. Beechey, Y.H. Edwards, and J. Peters. 1996. Glomerular-specific imprinting of the mouse $\mathrm{GS} \alpha$ gene: How does this relate to hormone resistance in Albright hereditary osteodystrophy? Genomics 36: 280-287.

Wong, J., D. Patterton, A. Imhof, D. Guschin, Y.-B. Shi, and A.P. Wolffe. 1998. Distinct requirements for chromatin assembly in transcriptional repression by thyroid receptor and histone deacetylase. EMBO J. 17: 520-534.

Wutz, A., O.W. Smrzka, N. Schweifer, K. Schellander, E.F. 


\section{CONSTÂNCIAETAL.}

Wagner, and D.P. Barlow. 1997. Imprinted expression of the I gf $2 \mathrm{r}$ gene depends on an intronic CpG island. Nature

389: 745-749.

Xu, Y., C.G. Goodyer, C. Deal, and C. Polychronakos. 1993. Functional polymorphism in the parental imprinting of the human IGF2R gene. Biochem. Biophys. Res. Commun.

197: $747-754$.

Yang, T., T.E. Adamson, J.L. Resnik, S. Leff, R. Wevrick, U. Francke, N.A. Jenkins, N.G. Copeland, and C.I. Brannan. 1998. A mouse model for Prader-Willi syndrome imprinting center mutations. Nature Genet. 19: 25-31.

Yoder, J.A., C.P. Walsh, and T.H. Bestor. 1997a. Cytosine methylation and the ecology of intragenomic parasites. Trends Genet. 13: 335-340.

Yoder, J.A., N.S. Soman, G.L. Verdine, and T.H. Bestor. 1997b. DNA (cytosine-5)-methyltransferases in mouse cells and tissues. Studies with a mechanism-based probe. J. Mol. Biol. 270: 385-395.

Zhang, X.-Y., N. Jabrane-Ferrat, C.K. Asiedu, S. Samac, B.M. Peterlin, and M. Ehrlich. 1993. The major histocompatibility complex class II promoter-binding protein RFX (NF-X) is a methylated DNA-binding protein. Mol. Cell. Biol. 13: 6810-6818. 


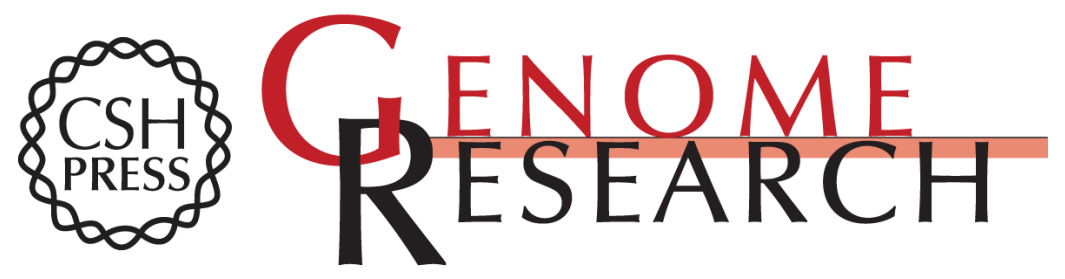

\section{Imprinting Mechanisms}

Miguel Constância, Benjamin Pickard, Gavin Kelsey, et al.

Genome Res. 1998 8: 881-900

Access the most recent version at doi:10.1101/gr.8.9.881

\section{License}

Email Alerting Receive free email alerts when new articles cite this article - sign up in the box at the Service top right corner of the article or click here.

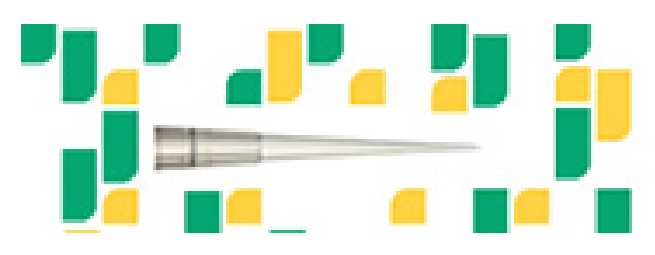

To subscribe to Genome Research go to: https://genome.cshlp.org/subscriptions 